\title{
Use of therapeutic factors for the evaluation of results in support groups*
}

\author{
Uso de fatores terapêuticos para avaliação de resultados em grupos de suporte
}

Uso de factores terapéuticos para la evaluación de resultados en grupos de soporte

\begin{abstract}
Objective: To identifyg the evidence of Therapeutic Factors (TF) for the systematized evaluation of a support group. Methods: Descriptive study developed in a hospital in Goiânia - GO, in 2005/2006. Ten sessions of the Inpatient Family Support Group (GRAF) were registered with a digital recorder, field journal and a check list filled out by the coordinators in order to identify TF observed in the participation of each family member. Later, these records were cross-checked so as to analyze this participation. Results: GRAF had an average of 6.9 participants per session. The following TF were identified: universality, imparting of information, cohesiveness, existential factors and instillation of hope. Conclusion: These TF were useful in the evaluation of the GRAF results, suggesting their convenience to evaluate results in other support groups.
\end{abstract}

Keywords: Group processes; Self-help groups; Intensive care units; Family

\section{RESUMO}

Objetivo: Identificar a evidência de Fatores Terapêuticos (FT) para a avaliação sistematizada de um grupo de suporte. Métodos: Pesquisa descritiva desenvolvida em um hospital de Goiânia - GO, em 2005/2006. Dez sessões do Grupo de Apoio aos Familiares (GRAF) de pacientes internados foram registradas em gravador digital, diário de campo e em check list preenchido pela coordenação para identificar FT observados na participação de cada familiar. Posteriormente, esses registros foram relacionados para analisar tal participação. Resultados: O GRAF teve média de 6,9 participantes por sessão. Foram identificados os FT: universalidade, oferecimento de informações, coesão, fatores existenciais e instilação de esperança. Conclusão: Estes FT foram úteis na avaliação dos resultados do GRAF, sugerindo sua conveniência também para avaliar resultados de outros grupos de suporte.

Descritores: Processos grupais; Grupos de auto-ajuda; Unidades de terapia intensiva; Família

\section{RESUMEN}

Objetivo: Identificar la evidencia de Factores Terapéuticos (FT) para la evaluación sistematizada de un grupo de soporte. Métodos: Investigación descriptiva desarrollada en un hospital de Goiânia - GO, en los años 2005/2006. Diez sesiones del Grupo de Apoyo a los Familiares (GRAF) de pacientes internados fueron registradas en una grabadora digital, diario de campo y en una lista de chequeo llenada por la coordinación para identificar FT observados en la participación de cada familiar. Posteriormente, esos registros fueron relacionados para analizar tal participación. Resultados: El GRAF tuvo un promedio de 6,9 participantes por sesión. Fueron identificados los FT: universalidad, ofrecimiento de informaciones, cohesión, factores existenciales e instilación de esperanza. Conclusión: Estos FT fueron útiles en la evaluación de los resultados del GRAF, sugiriendo su conveniencia para evaluar, también, resultados de otros grupos de soporte.

Descriptores: Procesos de grupo; Grupos de autoayuda; Unidades de terapía intensiva; Família

\footnotetext{
* The study was performed in Goiania/GO, at the Clinical and Surgical ICUs of the Hospital das Clinicas at Universidade Federal de Goiás, from December, 2005 till April, 2006.

${ }^{1}$ Doctor, Associate Professor at Faculdade de Enfermagem of Universidade Federal de Goiás - UFG - Goiânia (GO), Brazil.

${ }^{2}$ Doctor, Associate Professor at Faculdade de Enfermagem of Universidade Federal de Goiás - UFG - Goiânia (GO), Brazil.

${ }^{3}$ Doctor, Adjunct Professor at Faculdade de Enfermagem of Universidade Federal de Goiás - UFG - Goiania (GO), Brazil.

${ }^{4}$ Medical Student of Universidade Federal de Goiás - UFG - Goiania (GO), Brazil.

${ }_{5}^{5}$ Doctor, Professor at Faculdade de Enfermagem of Universidade Federal de Goiás - UFG - Goiania (GO), Brazil.
} 


\section{INTRODUCTION}

The human group is a complex entity. Researchers interested in knowing its dynamics, functioning and processes have been looking at it for a long time. This study focuses on the group understood as a living organism, a distinct entity with internal laws and standards, defined as more than the sum of its individuals ${ }^{(1-3)}$. The group, in the present research, integrates a number of people in a psychological interaction, with common interests and goals ${ }^{(3-5)}$.

The use of groups as a resource to help people has been studied since the early $20^{\text {th }}$ century, and has become an option for care delivery to people with several needs ${ }^{(2)}$, as it has been verified that contact among people with similar experiences can exert a positive influence. When they realize that they are not the only ones undergoing a situation of crisis, the members of the group share mutual forms of coping and support ${ }^{(2,3,5)}$.

There are several types of groups, classified according to different criteria. This study is specifically about support groups, whose primary goal is to maintain the existing strength, focused on trust and reinforcing the environmental and personal resources of its members ${ }^{(6-7)}$. Their benefit resides in mutual support and sharing of experiences among people who live similar situations, with the potential to prevent the development of misguided coping patterns and encourage healthy behaviors ${ }^{(6)}$.

An excellent co-adjuvant therapeutic resource to deal with people undergoing situations of crisis, the support groups help improve self-esteem and self-confidence, becoming an appropriate strategy for nurses to work with clients undergoing stress related to several types of health problems ${ }^{(1,6-10)}$. The group approach facilitates emotional care and permits easing the discomfort experienced during the disease process. The support groups constitute spaces that favor the manifestation of feelings, understanding and acceptance of the disease and the process that comes along ${ }^{(1,6,11)}$. The main realization for members of these groups is that they can obtain more help from people who have already experienced or who are experiencing a situation like theirs, than from people who have never been through this experience ${ }^{(6-7)}$.

However, like in every therapeutic intervention, the clients may benefit from the group or not. The participants' satisfaction is considered an essential indicator to evaluate the efficiency of support groups ${ }^{(5,12-13)}$, making it necessary to study forms to measure their results. The evaluation of the group process can be facilitated with the use of tools, especially those that help to explain how people change in groups ${ }^{(2-3,14-17)}$.

The mechanisms experienced by the group participants which help in the process of comprehension, adaptation and behavioral change are named healing or therapeutic factors (TF), and have been described as potential mechanisms of change in psychotherapeutic group participants ${ }^{(3)}$. However, they can also be found in other types of groups, including support groups, making it possible to understand how they help in changing the different participants within the same group ${ }^{(2-3)}$.

By working with Intensive Therapy inpatients' family members in support groups while they waited for their daily visits, it was observed that they valued the experience with people undergoing the same situation, to the extent that it helped them to overcome difficulties. Therefore, this research was performed with the goal of identifying aspects that indicate this help by investigating the TF present in the support group context.

This study was performed in view of the limitation of studies about TF evaluation in Brazil ${ }^{(15)}$ and the importance of developing investigations that make this kind of experiences available, with a view to the effective evaluation of non-psychotherapeutic group interventions. Hence, the objective outlined for this research was to identify the evidence of TF in a support group, performed with family members of intensive care inpatients as a way of evaluating the efficacy of this type of intervention.

\section{METHODS}

Type, place and period of the study: This is a formative and evaluative descriptive study, whose application is adequate to evaluate programas, care, practices or policies of something that is still being implanted ${ }^{(18)}$. The study was performed in Goiânia/GO, at the Clinical and Surgical ICUs of the Hospital das Clínicas at Universidade Federal de Goiás, from December, 2005 till April, 2006.

Study context, population and ethical concerns: A Family Support Group (GRAF) was created for the execution of this study. The group was planned as an open group, with goals of information and support, whose objective was to provide information and emotional support to the family members of patients in both ICUs, with a view to helping to satisfy their needs and collaborating with the process of welcoming these people at the institution.

The group was coordinated by one of the researchers and by an auxiliary coordinator with group work experience, supervised by a specialist nurse, consultant in Group Management and Dynamics, member of Sociedade Brasileira de Psicoterapia, Psicodrama e Dinâmica de Grupo (SOBRAP/Seção Goiás). It should be noted that this kind of interventions require specialized professionals, with theoretical-practical expertise, capable of handling emergent situations in this context.

The group meetings occurred in a classroom near the 
ICUs, at a time close to the evening visit times, aiming to make it easier for the people interested to participate. Sessions happened three times a week, with all visitors/ family members of patients who were willing to participate, regardless of whether they belonged to the same family. The group activity was developed in three stages: warm-up, development and evaluation ${ }^{(2)}$, and based on the precepts of group dynamics ${ }^{(19)}$.

The inclusion criteria adopted for the population were age, which had to be 18 years or older, and acceptance to participate in the group. The investigation was approved by the Review Board of the Hospital das Clínicas/UFG, Protocol No. 107/04, and the participation of the family member in the group was conditioned to signing the Term of Consent. The inclusion of subjects was voluntary, with individual support being offered in case of need.

Data collection: The group sessions were led by a coordinator, aided by a co-coordinator who was in charge of registering the meeting with a digital recorder and a field journal. The base to register the TFs was their description, based on Yalom and Lezcsz's theoretical reference $^{(3)}$, as observed in Chart 1.

At the end of each meeting, the coordinators discussed their impressions and perceptions of the facts occurred and the phenomena observed, and consensually filled out a check list ${ }^{(7)}$ to identify the TFs observed in the participation of each family member, considered as indicative parameters of group effectiveness. The elaboration of the check list was based on the Q-sort of healing and therapeutic factors ${ }^{(3,7)}$ and included all TF contained in the original roster, except for corrective reedition of the primary family group and catharsis, which occur more often in psychotherapeutic than in informative groups. The group sessions and the records were discussed in supervision sessions.

Data analysis and organization: the recordings were transcribed after the session, along with the notes of the field journal, aiming to identify facts and phenomena that would detect the presence of TF in each session. Later, the sessions were compared in order to identify common patterns and peculiarities for TF analysis and description. In the following stage, the TF registered in each session's check list were cross-referenced with the registers about the participation of the family members in the meetings, aiming to qualify each identified factor.

For the presentation of results, the participants received fictitious names to preserve their identity, and their expressions were transcribed integrally.

\section{RESULTS}

The amount of participants per session varied from 3 to 15 , averaging at 6.9 . In total, 51 family members of 17 patients took part in the GRAF. A majority (43 $84.3 \%$ ) participated in a single session, five $(9.8 \%)$ in two and only three $(5.9 \%)$ in five or more meetings. Of the 17 patients whose relatives participated in the GRAF, 11

Chart 1 - Therapeutic factors described by Yalom and Lezcsz (3)

\begin{tabular}{|c|c|}
\hline Therapeutic factors & Description \\
\hline Instillation of hope & $\begin{array}{l}\text { Hope for cure or that things can be different, present from living with people who experience a } \\
\text { similar situation. }\end{array}$ \\
\hline Universality & $\begin{array}{l}\text { Strongly related to instillation of hope, allows the members of the group to realize that they are } \\
\text { not the only ones to experience a problem. }\end{array}$ \\
\hline $\begin{array}{l}\text { Imparting of } \\
\text { information }\end{array}$ & Includes all the technical information and orientation provided by the coordination of the group. \\
\hline Altruism & Regards the fact of sharing a part of oneself with the other members of the group. \\
\hline $\begin{array}{l}\text { Corrective } \\
\text { recapitulation of the } \\
\text { primary family group }\end{array}$ & $\begin{array}{l}\text { Since the group is formed by people who can be seen as siblings and by the leader, who can be } \\
\text { seen as a father figure, the members can start to interact with each other of with the leader in the } \\
\text { same way they interact with their primary family group in some moment of life, by reviewing } \\
\text { previous family experiences. }\end{array}$ \\
\hline $\begin{array}{l}\text { Development of } \\
\text { socializing techniques }\end{array}$ & $\begin{array}{l}\text { The skill of relating directly, honestly and intimately with other people from the group may be a } \\
\text { secondary achievement. }\end{array}$ \\
\hline Imitative behavior & $\begin{array}{l}\text { In the group, both the leader and the other members become role models of newer and healthier } \\
\text { behaviors. Imitation can be the first step for the internalization of new behaviors and values. }\end{array}$ \\
\hline Interpersonal learning & $\begin{array}{l}\text { Opportunities to experience similar situations, within and outside the group promote changes in } \\
\text { personal behavior, clarifying difficulties, finding alternatives to face problems and experimenting } \\
\text { new behaviors. }\end{array}$ \\
\hline Group Cohesiveness & $\begin{array}{l}\text { Member relations with the coordinator, other participants and the group as a whole. Described as } \\
\text { the result of all the strengths acting on each participant for him or her to remain in the group. }\end{array}$ \\
\hline Catharsis & $\begin{array}{l}\text { Expression of the emotions, linked to other processes in the group, particularly to universality } \\
\text { and cohesiveness. By itself, rarely produces lasting changes for the patient, although it can } \\
\text { promote a feeling of relief. }\end{array}$ \\
\hline Existential factors & $\begin{array}{l}\text { Elements in the group process that help dealing with the precepts of human existence: death, } \\
\text { isolation, freedom, lack of meaning. }\end{array}$ \\
\hline
\end{tabular}


$(64.7 \%)$ were at the Surgical ICU and $6(35.3 \%)$ at the Clinical ICU. The participants who participated most were relatives of patients with longer hospital stays and belonged to families in which many members were involved and experiencing this situation with their loved one.

\section{Presence of therapeutic factors in the GRAF}

The evaluation of the TF in the group activity is fundamental to identify the mechanisms of the participants' process of change. It is a complex process, resulting from the interaction among human experiences. These factors are interdependent and the identification of those involved in the change of the group members helps to choose strategies to promote more productive group experiences ${ }^{(3)}$.

In this study, the presence of the TF in the group sessions was evaluated according to the point of view of the coordination, aiming to identify suggestive expressions of each member's presence, in the field journal entries, in the meeting recordings and in the check list ${ }^{(7)}$ of each meeting.

Although the process of change in the psychotherapeutic groups usually includes all TFs, those identified in the GRAF (universality, group cohesiveness, imparting of information, existential factors and instillation of hope) are those usually observed in any group, whereas others are more common in groups with psychotherapeutic goals ${ }^{(3)}$.

Universality was the only factor observed in all group meetings (100\%), identified in the following statements:

"That's why the group is important (...) you see it's not only you who's going through it, many people are in the same situation." (Vanda)

"When I saw those people there, they were all suffering like me... It's not that I felt good to see them suffer, but, you know... it seems like we're relieved when we see we're not the only ones, right? (...) it relieved the grief, you know what I'm saying?" (Eugênia)

"Everybody with different names and from different sectors, but with the same problems and the same difficulties..." (Luana).

Group cohesiveness and imparting of information were two factors present in $90 \%$ of the meetings.
Cohesiveness was identified in the following statements:

"We never feel alone, do we?" (Maristela)

"We're becoming a big family, aren't we?" (Luana)

"I'm feeling very happy about being with all of you here... it's like it were someone from my own family..." (Elina)

"We know that everybody here is friendly and knows exactly what you're feeling... We speak and we know the others understand what you're saying..." (Paulo)

"You can feel that everyone is friendly... nobody is there to poke their noses in your life..." (Dionízio)

In other recordings, the GRAF participants confirmed the usefulness of the group to convey information and orientation:

"That day you explained that ICU is not the end of the world, that the ICU is the most favorable place for the doctors to care, which has better conditions of helping, it was... I felt a little relieved, and it's still relieving. This meeting of yours (...) awakened me to more things I did not know about. (...) I was still neutral in certain hospital knowledge and today I've got it." (Marcos)

"... we learn things that we'd never know about if it weren't there, or if we didn't ask someone at the ICU... but the nurses there are very busy, aren't' they? When we meet them, we try to ask the things that we need to ask more urgently, and other things are left aside for later..." (Vanda)

"That's why the group is important (...) you exchange experiences, ideas..." (Vanda)

"Talking is very good, isn't it, it helps, doesn't it... we learn a lot of stuff." (Paulo)

Existential factors were identified in $70 \%$ of the GRAF sessions, according to the statements of some participants:

"That's part of life, isn't it? (...) It's not because of the stuff we face in life that well get sad, right?" (Maristela)

"You see that... besides suffering because of the disease, you see that you can use this knowledge in other areas, you know, and know that... difficulties exist." (Isabela).

"We can't lose hope (...) life is precious and some people just throw it away. (...) Life must go on (...). We have to go through problems as God dictates, not as we do... we have no right... what He sends us is what we deserve. This is really luck, the fate of the

Chart 2 - Therapeutic factors identified in the sessions of the Inpatient Family Support Group sessions. Goiânia, 2006

\begin{tabular}{|l|c|c|c|c|c|c|c|c|c|c|c|}
\hline \multirow{2}{*}{ Therapeutic factors } & \multicolumn{9}{|c|}{ Session } \\
\cline { 2 - 13 } & $1^{\text {st }}$ & $2^{\text {nd }}$ & $3^{\text {rd }}$ & $4^{\text {th }}$ & $5^{\text {th }}$ & $6^{\text {th }}$ & $7^{\text {th }}$ & $8^{\text {th }}$ & $9^{\text {th }}$ & $1^{\text {th }}$ \\
\hline Universality & $\mathrm{x}$ & $\mathrm{x}$ & $\mathrm{x}$ & $\mathrm{x}$ & $\mathrm{x}$ & $\mathrm{x}$ & $\mathrm{x}$ & $\mathrm{x}$ & $\mathrm{x}$ & $\mathrm{x}$ \\
\hline Group Cohesiveness & $\mathrm{x}$ & & $\mathrm{x}$ & $\mathrm{x}$ & $\mathrm{x}$ & $\mathrm{x}$ & $\mathrm{x}$ & $\mathrm{x}$ & $\mathrm{x}$ & $\mathrm{x}$ \\
\hline Universality & $\mathrm{x}$ & $\mathrm{x}$ & $\mathrm{x}$ & $\mathrm{x}$ & & $\mathrm{x}$ & $\mathrm{x}$ & $\mathrm{x}$ & $\mathrm{x}$ & $\mathrm{x}$ \\
\hline Group Cohesiveness & $\mathrm{x}$ & & $\mathrm{x}$ & & $\mathrm{x}$ & & $\mathrm{x}$ & $\mathrm{x}$ & $\mathrm{x}$ & $\mathrm{x}$ \\
\hline Instillation of hope & & $\mathrm{x}$ & & & & & $\mathrm{x}$ & $\mathrm{x}$ & $\mathrm{x}$ & $\mathrm{x}$ \\
\hline
\end{tabular}


person. (...) since the day it's conceived, it has that... certainty about the tasks you'll have to do. Because (...) the work we have to do (...) we deserve that. From the moment we're buman, each one has his deepest pain..." (Dionizio).

Observed in $50 \%$ of the sessions, instillation of hope was the least frequently identified factor in the group context, but not the least important, as observed in the statements of the participants. It was related to the benefits of simple participation in the group, represented by the opportunity of having someone willing to listen to them and being able to speak about what afflicted them, or, in other words, to feel welcomed:

"... we become so fragile when there's a relative like my sister was, that when you get some attention, whoever it is from, you're relieved, hopeful. That's why the group is important..." (Vanda).

"That woman [Sonia] (...) was so nice to me... Just having her say (...) that she'd already been through that (...) that she had felt the same I was feeling at the time... that was... that was like medicine at the time I needed it... It seems like (...) when you see someone who was also feeling that bad (...) and is still there, alive... she survived, right?" (Eugênia)

"I'll leave this place full of hope." (Eunice)

"I (...) have participated in the meetings here since the day I found out about it, and I want to keep doing it while I can, right? (...) I leave the reception feeling satisfied and optimistic about what's to come..." (Marcos)

"Today is the first time that I (...) take part in this meeting and I'm feeling real good, and it's thanks to both of you, that will give us more strength! I'm leaving and feeling a lot better..." (Régis).

The factors development of socialization techniques, imitative behavior, altruism and personal learning were not observed in the context of this investigation.

\section{DISCUSSION}

The presence of the TF identified at the group meetings and referenced in the participants' statements reveals that the GRAF helped its participants in the process of understanding and adapting to the experienced situation, being an adequate strategy to meet informational and emotional support needs of ICU inpatients' family members.

The absence of some TF that were part of the group's registry instrument (development of socialization techniques, imitative behavior, altruism and interpersonal learning) can be directly related to the theoretical-technical focus of the GRAF as an open group. Since it was a group without psychotherapeutic objectives, with a preestablished number of sessions and whose participants varied at each meeting, there were interferences in intragroup relations and, consequently, in their results. A longer- lasting bond between the group members and the coordinators would be necessary for these factors to $\operatorname{occur}^{(3)}$.

On the other hand, some factors are expected to be more evident and constant ${ }^{(3)}$. Among the most frequently observed TF in the present study, universality, cohesiveness and imparting of information were confirmed in another study ${ }^{(20)}$ as more common in support and self-help groups, because they helped to decrease fear, anxiety and isolation related to a particular situation. Nevertheless, the therapeutic process involved in the groups is complex and encourages changes through experience, so that no TF system or group can explain the whole process ${ }^{(3)}$.

Universality is present in expressions indicating that the participation in the group allows people to realize that they are in the same situation as others, have the same sources and reasons for unhappiness and are not too different from the others ${ }^{(2-3)}$. Experiences related to universality have also figured among the most frequently mentioned by group participants in other studies ${ }^{(14-17,20)}$. It is common for the participants to arrive at the group feeling as if they are the only ones with that kind of problem, that their problems are more serious than those of other people and that they are the only ones who have feelings or thoughts that are not very acceptable. Certainly, each person's problem may be really experienced as the most important and grave at that moment, but their participation in the group may ease this perception, by showing them that this experience is not exclusive to them, which may bring some relief ${ }^{(7)}$.

Cohesiveness is not only a therapeutic factor; but also a human condition for other factors to be efficient ${ }^{(3)}$. The good development of the therapeutic process is based on the establishment of group cohesiveness, favored by the homogenous composition of the group ${ }^{(20)}$. In groups with strong cohesiveness, the participants feel like they belong to the group, experiencing affection and comfort, valuating the group and feeling valued, accepted and welcomed by the other members. This movement enhances trust for the expression of feelings ${ }^{(3,5)}$.

The GRAF participants revealed the presence of this therapeutic factor by highlighting the importance of not feeling alone, of feeling that they belonged to a group made up of other people who can be trusted as if they were their own family. In group cohesiveness, it is important not only to discover that other people have the same problems, but the possibility of affectionately sharing experiences and acceptance by the others ${ }^{(3)}$.

Imparting information includes didactic instruction, counseling, suggestions and practical orientation about the problems presented by the participants, offered by the coordination or other members of the group. In general, the participants learn a lot, even if the educational process is not explicit, provided that it happens in an 
environment of collaboration and partnership as opposed to one of prescription and subordination ${ }^{(1,4,9)}$. In specialized groups for people with some specific disorder, or who face a situation of crisis, besides mutual support, it is important to offer explicit information about the themes involved and correct wrong conceptions or selfdestructive responses ${ }^{(3)}$.

Studies with families undergoing critical situations ${ }^{(8,12,17,20-21)}$ show that this factor was made evident by the sincere exchange of information as the first attempt to solve problems in the group. The participants of a group for parents of adolescents maladjusted behavior ${ }^{(20)}$ also reported practical benefits obtained from hared information and solutions, based on what had worked for other members.

Existential factors related to existential questions of the human condition can be identified by expressions indicating acknowledgment that life sometimes is not fair and that there is no way to escape from death or some of the pains of life. They are also present when, regardless of orientation and support received, they express full responsibility for leading their lives and that there is a limit to the help they receive from others, after which they must go on by themselves ${ }^{(3)}$.

Members of support groups can obtain psychological, emotional and even physical benefits from the support received from the other participants for a significant involvement in the challenges of life ${ }^{(11-12)}$. Some testimonies of GRAF participants showed certain aspects of the existential factors related to the truths of life, acceptance of the experienced difficulties as inherent to human condition and the need not to let themselves be hit too hard by pain and sadness.

The manifestations related to hope are usually expressed by observing that other people in a similar situation have solved similar problems, that other participants improved their lives, or even that the group has helped other people with the same problem ${ }^{(2-3)}$. However, it can take variable forms, according to the situation experienced, such as the hope for comfort, dignity or reduction of discomfort ${ }^{(3)}$.

In any group, instillation and maintenance of hope are fundamental to encourage the person to remain in the group to receive help. Thinking about this possibility, the coordinator can use strategies that help in the task of strengthening the participants' belief and trust in the efficiency of the group ${ }^{(4,19)}$. It is important to reinforce positive experiences, correct prejudices, provide

\section{REFERENCES}

1. Godoy MTH, Munari DB. Review of scientific literature on the use of group activities in nursing work in Brazil: 1980 to 2003. Rev Latinoam Enferm. 2006; 14(5):796-802.

2. Munari DB, Furegato AR. Enfermagem e grupos. 2a ed. Goiânia: Ab; 2003. explanations about the power of the group to help people and encourage the testimony of participants who had already attended other sessions about their improvement. Besides, since the groups usually integrate people in different stages of coping, contact with other members who showed improvements in function of their participation in the group works as a source of hope ${ }^{(3)}$.

The statements of the GRAF participants denote the importance of receiving effective help to cope with their difficulties, or simply being heard, evidencing the relevance of this type of work in care for their necessities manifested during coping with the disease and the hospital stay of a loved one.

\section{FINAL CONSIDERATIONS}

The presence of most TF in the GRAF sessions confirmed that, although being described as therapeutic elements of psychotherapeutic groups, they can be identified in support groups and also be useful in the evaluation of their results. The therapeutic value of the support groups lies in the possibility of favoring the action of certain TF that help their members to cope with the crisis experienced. In the GRAF, the benefits for the family members showed to be a consequence of both the therapeutic experiences made possible by sharing experiences with other people in similar situations and the support provided by professionals and other group members, which helped to cope with the threat of loss, among other aspects.

The results of this investigation also highlight the importance of mechanisms like support, room for listening and opportunities to share feelings and thoughts, aspects that are not included in the TF list adopted by the theoretical reference framework. Several participants mentioned positive effects of the GRAF, simply deriving from the opportunity to speak about feelings, fears and concerns, knowing that they would be heard. However, it is worth noting that, regardless of the focus, the conduction of group work requires specifically-prepared professionals to meet the needs and movement of the group.

Evidence of TF in an open group shows that these, when conducted adequately, become excellent instruments of aid; however, considering the low number of studies assessing the efficiency of group interventions, other investigations are necessary to better outline the most common TF in this type of group.
3. Yalom ID, Leszcz M. Psicoterapia de grupo: teoria e prática. Porto Alegre: Artmed; 2006.

4. Munari DB, Padilha GC, Motta KAMB, Medeiros M. Contribuições para a abordagem da dimensão psicológica dos grupos. Rev Enferm UERJ. 2007; 15(1):107-12. 
5. Petersen LE, Dietz J, Frey D. The effects of intragroup interaction and cohesion on intergroup bias. Group Proc Intergr Relat. 2004; 7(2):107-18.

6. Campos EP. Grupos de suporte. In: Mello Filho J, Pereira AP, Escobar ACS, Villwock CAS, editors. Grupo e corpo: psicoterapia de grupo com pacientes somáticos. Porto Alegre: Artmed;2000. p. 117-30.

7. Oliveira LMAC. O acolhimento de familiares de pacientes internados em UTI: a tecnologia de grupo como estratégia para o cuidado de enfermagem [tese doutorado]. Goiânia: Universidade Federal de Goiás; 2006.

8. Chien WT, Chan S, Morrissey J, Thompson D. Effectiveness of a mutual support group for families of patients with schizophrenia. J Adv Nurs. 2005; 51(6):595-608.

9. Gonçalves LHT, Scheir J. Grupo aqui e agora: uma tecnologia leve de ação sócio-educativa de enfermagem. Texto \& Contexto Enferm. 2005; 14(2):271-9.

10. Merkling J. [Group therapy activities and the nursing intention]. Soins Psychiatr. 2007; (248):41-5. French.

11. Goodwin PJ, Leszcz M, Ennis M, Koopmans J, Vincent L, Guther H, et al. The effect of group psychosocial support on survival in metastatic breast cancer. N Engl J Med. 2001; 345(24):1719-26. Comment in: Evid Based Nurs. 2002; 5(3):82. N Engl J Med. 2001; 345(24):1767-8. N Engl J Med. 2002; 346(16):1247-8; author reply 1247-8. N Engl J Med. 2002; 346(16):1247-8; author reply 1247-8.

12. Bragadóttir H. Computer-mediated support group intervention for parents. J Nurs Scholarsh. 2008; 40(1):32-8.

13. Statham J, Holtermann S. Families on the brink: the effectiveness of family support services. Child Fami Soc Work. 2004; 9(2):153-66.

14. Choi YH, Park KH. Therapeutic factors of cognitive behavioral group treatment for social phobia.J Korean Med Sci. 2006; 21(2):333-6.

15. Guanaes C, Japur M. Fatores terapêuticos em um grupo de apoio para pacientes psiquiátricos ambulatoriais. Rev Bras Psiquiatr. 2001; 23(3):134-40.

16. Holmes SE, Kivlighan DM. Comparison of therapeutic factors in group and individual treatment processes. J Couns Psychol . 2000; 47(4):478-84.

17. Shechtman Z, Gluk O. An investigation of therapeutic factors in children's groups. Group Dyn. 2005; 9(2):127-34.

18. LoBiondo-Wood G, Harber J. Pesquisa em enfermagem: métodos, avaliação crítica e utilização. 4a. ed. Rio de Janeiro: Guanabara Koogan; 2001.

19. Motta KAMB, Munari DB, Leal ML, Medeiros M, Nunes FC. As trilhas essenciais que fundamentam o processo e desenvolvimento da dinâmica grupal. Rev Eletronica Enferm. 2007; 9(1):229-41.

20. Vinogradov S, Yalom ID. Manual de psicoterapia de grupo. Porto Alegre: Artes Médicas; 1992.

21. Häggman-Laitila A, Pietilä AM. Perceived benefits on family health of small groups for families with children. Public Health Nurs. 2007; 24(3):205-16. 